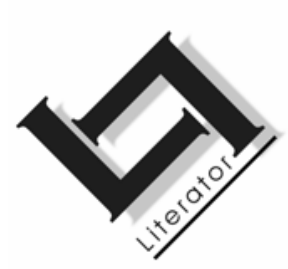

\title{
Symbolism in the poetry of S.M. Burns-Ncamashe
}

\author{
Z. Mtumane \\ Department of African Languages \\ University of Johannesburg \\ JOHANNESBURG \\ E-mail: mtmne-z@rau.ac.za
}

\section{Abstract}

\section{Symbolism in the poetry of S.M. Burns-Ncamashe}

In the introductory part of this article it is attempted to define the concept "symbolism". This article examines the use of symbols and the symbolism embedded in the poetry of S.M. BurnsNcamase. The symbols to be investigated include those alluding to authority, grief, witchcraft, good motherhood and strength. The aim of the discussion is to reveal the nature of the specific symbols the poet uses and the domains of reality that he explores and represents by means of certain symbols.

The poetry of Burns-Ncamashe to be considered in the ensuing discussion includes poems in the following volumes: Masibaliselane (1961), Izibongo zakwaSesile (1979) and those found in Tonjeni (1959). Poems on tapes (see $T(X H / 93) 28$, $T(X H / 90) 317, T(X H / 90) 322$ and $T(X H / 96) 5)$ will also be considered for this discussion, as well as the unpublished poem "Aa! Dalubuhle". In the concluding section a brief summary of the discussion and some findings are highlighted.

\section{Opsomming}

\section{Simboliek in die poësie van S.M. Burns-Ncamashe}

In die inleidende gedeelte van hierdie artikel word gepoog om die konsep "simboliek" te defineer. Hierdie artikel ondersoek die gebruik van simbole en die simboliek wat opges/uit lê in gedigte van S.M. Burns-Ncamashe. Die simbole wat ondersoek word, sluit onder andere dié in wat verwys na gesag, smart, toorkuns, goeie moederskap en krag. Die bespreking is daarop gemik om die aard van die simbole wat die digter gebruik asook die 
domeine van die werklikheid wat hy met sy simbole ondersoek aan die lig te bring.

Die gedigte van Burns-Ncamashe wat vir die daarop volgende bespreking oorweeg is, sluit gedigte in die volgende bundels in: Masibaliselane (1961), Izibongo zakwaSesile (1979), asook gedigte wat opgeneem is in Tonjeni (1959). Gedigte wat op band opgeneem is ( $T(X H / 93) 28, T(X H / 90) 317, T(X H / 90) 322$ en $T(X H / 96) 5)$ sowel as the ongepubliseerde gedig "Aa! Dalubuhle" word ook betrek. Die artikel word afgesluit met 'n samevatting van die bespreking en enkele bevindings.

\section{Introduction}

Very little attention has been given to Burns-Ncamashe's use of symbolism in his poetry although his poetry is rich in this aspect. The only scholar who has probably studied this aspect of the poet's work till date is Mtumane (2000). The aim of this article then is to reveal the usage of symbolism in the poetry of S.M. BurnsNcamashe. The specific domains of reality (different "worlds") from which the poet takes his symbols will also be investigated. These "worlds" may represent the animal, plant, human and cosmic world as well as the domain of biblical references. The discovery of these worlds will in turn point to the nature of symbols employed by the poet, as they may be symbols related to plants, humans, animals and others. This article will attempt to indicate what is accomplished by the use of symbolism in the poems under discussion. Generally, as an element of imagery, the use of symbolism tends to decorate poetry. It also serves as an instrument by which the reader's intellectual abilities are challenged, as it stimulates his mental capacity to understand what the poet is actually communicating in a poem In addition the meaning of a poem is clarified when the reader has discovered what the symbols refer to. In this article the symbols' contribution towards communication in Burns-Ncamashe's poetry will be highlighted. It will also be indicated whether BurnsNcamashe's use of symbols does accomplish the said issues.

As the discussion in this article focuses on the use of symbolism by which meaning is produced, the discussion takes place within the framework of semiotics, which emphasises the use of images, signs and symbols by which meaning is created and produced. In the discussion it will be attempted to indicate what the symbols used in Burns-Ncamashe's poetry signify (Abrams, 1993:237-239; Baldick, 1990:232-233). 


\section{Symbolism defined}

In the words of Mtumane (2000:242) symbolism and the use of symbols are features of quality poetry. A symbol entails the use of an object, idea or incident to stand for or represent another. According to Shipley (1970:322) symbolism implies "the representation of a reality on one level of reference by a corresponding reality on another", in other words the object, idea or incident used as symbol is a reality that represents another reality. Concurring Shipley Grambs (1984:355) views symbolism as

the use of visible or palpable things as specific signs or tokens to represent things, forces, qualities, universal truths, etc.; signification through real or sensory objects or occurrences; the imaginative use in art or literature of animate or inanimate phenomena for meanings beyond the real or immediate world, invested or latent meaning.

What is implied in the passage above is that the object used as a symbol adds meaning that is beyond itself. A symbol is used to disclose a hidden meaning. Through it the reader's eye of imagination sees the invisible or hidden truth. Through a process of association this hidden truth is discovered.

Anything that is used to represent another is called a symbol, as a symbol is generally a visible or palpable object or idea that represents something else. In literature a symbol is a word, phrase or another expression with a complex of associative meaning. This word normally signifies an object or event, which points to something else or has a range of reference beyond itself (Abrams, 1993:206). A symbol is viewed as having values different from those of whatever is being symbolised (Shaw, 1972:367). Although a symbol may have values different from those of the symbolised, its use is normally based on some association with what is represented.

Burns-Ncamashe uses various symbols in his poetry. Symbols to be discussed in this article represent those referring to authority, grief, witchcraft, good motherhood and strength. Other symbols will be mentioned briefly towards the end.

\section{Authority}

Authority is generally associated with rulership. People who are in positions of rulership and power normally exercise some authority. In the animal world large and dangerous animals such as the lion 
and elephant are regarded as having some authority as they are feared by other animals. For this reason Burns-Ncamashe often uses the lion and the elephant as symbols of authority and power in his description of kings and chiefs. The use of these animals is evident in the following poems: "Intetho yohlanga Iwethu" ( $\mathrm{T}(\mathrm{XH} / 96) 5$; Burns-Ncamashe, [unpublished]); "UBazindlovu" ( $\mathrm{T}(\mathrm{XH} / 90) 322$; Burns-Ncamashe, 1977), "Umgoduko wokumkanikazi” (see Burns-Ncamashe,1961), "Umthomb' onzulu wamanz' olwazi" (see Burns-Ncamashe, 1979) and "Aa!! Gunyaziwe!" (Tonjeni, 1959). Regarding lions, the poet for instance says the following about Mxolisi Sandile (Bazindlovu) who was the supreme chief of amaRharhabe (a Xhosa sub-group):

Nanzo zibhonga neenkom' ebuhlanti komkhulu

Ukuxel' ukub' ifikil' ingonyama phakathi komzi.

(The cows are bellowing in the kraal of the great place

Indicating the arrival of the lion within the household.)

( $\mathrm{T}(\mathrm{XH} / 90) 322)$

The poem from which these lines are taken is in the form of a protest against the undermining of traditional leadership and the abuse of amaRharhabe by the political system of that time. The poet then appeals to the late Chief Mxolisi Sandile to intervene. The use of symbolism in the poem is apparent in the application of the image of a lion. The lion is an animal which is believed to be the king of the animal kingdom in the forest because of its viciousness and power. Most animals fear it and, as a result, the lion is often depicted in folktales as ruler in the animal kingdom. This fact is illustrated by Daba (1988:6) in the folktale "UDyakalashe nezilo" in which the lion summons a meeting of all the animals to make a decision about the problem a drought causes. In this poem Burns-Ncamashe uses the lion as symbol to enhance the authority of Mxolisi Sandile as the former supreme chief of amaRharhabe. In general the poet is pleading with Mxolisi to punish those who abuse the nation. This symbol is also used to suggest Mxolisisi's strength and viciousness in dealing with the abusers, and this idea is further confirmed by the warning:

Yeha-a! Nina bacudisi bosapho lukaBazindlovu nolukaVelile,

Yitshon' umhlab' uvuleke ningene nizimele,

Akwab' oonyoko babenganizalanga,

Kub' izakwenzek' impendulw' enengqumbo yeminyanya phakathi. 
(Wow! You oppressors of the family of Bazindlovu and Velile,

Tell the earth to open up for you to enter and hide,

How I wish your mothers never gave birth to you,

For a reaction involving the wrath of the ancestors is about to happen.)

\section{(T(XH/90)322; Burns-Ncamashe, 1977)}

These lines have been cited by Mtumane (2001:235) in his discussion of satire. They indicate the vicious and powerful manner, as the poet imagines, in which Bazindlovu will use his authority in his intervention on behalf of the oppressed.

The use of lion as a symbol to enhance one's authority is also found in the poem "Umnyaka omtsha", in which Velile, Xoliliziwe, Daliwonga, Jonguhlanga and Jongilizwe, who are/were important chiefs (and kings) in different parts of Xhosaland, are referred to as ezo ngonyama (those lions) ( $\mathrm{T}(\mathrm{XH} / 93) 28$; Burns-Ncamashe, 1967). This reference is based on these figures' having authority over the Xhosa nation, as they are the supreme chiefs of the different subgroups of that nation.

The use of the elephant as a symbol of authority is evident in the poem "Umthomb' onzulu wamanz' olwazi", in which the poet views God, whom he refers to as Ndlov' enomxhaka yasezulwini (the distinguished Elephant of heaven) (cf. Burns-Ncamashe, 1979:4), as having instituted that even the elephants and whales may not drink all the water and thus deplete all sources of water.

The elephant is one of the largest and most powerful animals in the forest. Its authority is regarded as almost on the same level as that of the lion, but the former is less vicious than the latter. The use of the elephant as symbol to refer to God is indicative of the authority God is regarded to have. His having instituted that even "elephants" and "whales" may not drink and consume all the water, is an indication that His authority surpasses even that of the most powerful creatures.

It is also worth noting that the elephant is generally regarded to be a docile and patient animal. That is the reason why people tend to play with and even ride on its back in for instance a zoo. It is befitting then that the elephant, because of its authority, kindness and patience, is used to symbolise God who is also generally regarded to have authority, to be kind and patient. 
Another instance where the elephant is used as a symbol of authority is found in the poem "UBazindlovu", in which Mxolisi Sandile is addressed as iNdlovu yamahlath' akwaMtshiza (the elephant of the forests of Mtshiza) ( $\mathrm{T}(\mathrm{XH} / 90) 322$; Burns-Ncamashe, 1977). This address is based on Mxolisi's having been the supreme chief of amaRharhabe. As the elephant is a huge animal, this address also indicates Mxolisi's stature, as the poet also describes him as ibhumbhum and imbishimbishi (the sturdy one).

It should be noted that Burns-Ncamashe mainly draws the symbols of authority from the animal world. His knowledge of the qualities and nature of these animals and the way in which they are generally seen, allow him to use them as symbols in the manner he does. Using these animals as symbols in the poem enables the reader to create some mental pictures of them and consider the way in which they are generally interpreted. The reader thus imagines the figures referred to in the poems as having the authority these animals are generally associated with. The reader's associating the animals with certain figures in the poems assists him to gain more insight into what is actually implied by the symbols used for these figures.

\section{Grief}

Grief is a painful feeling related to a bad experience such as the death of a loved one. The signs of grief, which are used by the poet, include tears, sores and wounds. The use of tears is apparent in the poem "Umgoduko wokumkanikazi":

Lonk'elakwaRharhabe lisemyembezini.

(The land of Rharhabe as a whole is in tears.)

(Burns-Ncamashe, 1961:7)

The poem from which this line is taken is an elegy about the death of Queen Nobantu Sandile; hence the nation is depicted as being in tears. Symbolism, in this line, is achieved by the use of an idiomatic expression (lisenyembezini: to be in tears) that refers to the nation's being in a state of grief. This effect is achieved by using tears as a symbol of grief. Tears are drops of liquid that come out of one's eyes usually because of some grievous experience one has had, among other things. Other instances where tears drop out of one's eyes can be caused by the sensation of joy or when the eye is irritated by a foreign element such as wind, dust and so on. In this article tears are, however, discussed as associated with grief. 
Grief is a phenomenon that cannot be seen, but sometimes when tears appear in one's eyes, it suggests that one is grieving. Since the death of a loved one is generally an experience of grief, the use of tears in the above excerpt undoubtedly indicates the grief of amaRharhabe, caused by the death of their queen mother (Nobantu Sandile). When it is later announced that the poet is without tears, it actually implies that he is not grieving any more; he has reached a stage of consolation.

The use of sores and wounds as symbols of grief is evident in the poem "Aa! Velile!" in which the following is said to Velile Sandile, who was the supreme chief of amaRharhabe before Mxolisi Sandile (already referred to in this article):

Ndakuzisel' izilonda namanxeb' aqaqambayo.

(I bring you painful sores and wounds.)

( $(\mathrm{XH} / 90) 317$; Burns-Ncamashe, 1976)

The poem from which this line is extracted also concerns the oppression of amaRharhabe by the political system of the time. In this poem an appeal is made to Velile to punish the oppressors. Sores and wounds are painful inflictions on one's body. The use of these inflictions suggests a painful or grievous situation that is brought to Velile's attention. Considering that the poet portrays a situation of undermining the traditional leadership and the abuse of subjects by political practices of the time, one may deduce that the sores and wounds referred to represent a resultant grievous state of and the condition of amaRharhabe in general.

The use of wound as symbol to represent grief is also evident in "Umgoduko wokumkanikazi", in which the poet views the death of Nobantu Sandile as inxeba (a wound) (Burns-Ncamashe, 1961:11).

The above discussion has indicated how Burns-Ncamashe draws his symbols of grief from the human world, as tears, sores and wounds are normally associated with people who experience some pain or grief. The poet's imagining the painful and grievous feeling associated with these inflictions enables him to use them as symbols of grief. Although tears, sores and wounds are visible inflictions, what is of essence here is the feeling they are generally associated with. Their use sensitises the reader to the feeling of pain and grief, and, therefore, contributes towards understanding clearly what the symbols refer to. This resultant understanding in the mind of the reader underscores the successful application of these symbols. 


\section{Witchcraft}

Witchcraft is the belief that evil magicians, in practice can either harm or kill people in society (Pearsall, 2001:1642; Mtumane, 1992:20-30). Witchcraft is believed to be practised by the use of some agents called familiars ${ }^{1}$. These familiars are usually animals and birds. These animals or birds are then generally regarded to be symbols of witchcraft among amaXhosa.

In his poetry Burns-Ncamashe uses the baboon and impundulu (the lightning bird) as symbols of witchcraft. The baboon is generally believed to be a kind of familiar among amaXhosa. While female witches are believed to use impundulu (the lightning bird), male ones are generally believed to use baboons to execute their witchcraft rituals. Males are believed to ride on baboons during the night or even send them to go and harm someone. In his description of the land where Rhodes University is situated, before the arrival of whites in this region, the poem 'Umthom' onzulu wamanz' olwazi" reads as follows:

Apho izihandiba bezikhwel' iimfene zazo ilanga lakusithela.

(Where great men would ride their baboons after sunset.)

(Burns-Ncamashe, 1979:4)

Riding baboons suggests that witchcraft was among the practices found in the area. Besides emphasising the negativity of witchcraft in the above line it is also suggests how freely black people could practise their cultural activities and beliefs in the area before the arrival of the white man who disturbed that freedom.

The poet also associates the riding of a baboon with witchcraft when he says the following about the person executing the initiation rituals of boys in the poem "Ingcibi yamakhwenkwe":

Yakubanjw' ikhwel' imfene

lligqwirha kusini na?

Mayenziw' itheth' inene.

(When he is caught riding the baboon

Can he be a witch?

1 Familiar: "A cat or other animal that lives with a witch and has magical powers" (Longmans, 1995:498). 
He should be made to speak the truth.)

(Burns-Ncamashe, 1961:21)

The poem from which these lines are extracted depicts the person performing the initiation rituals of boys (ingcibi) and his consecrated duty of circumcising boys. Generally this person is not expected to be involved in evil practices such as witchcraft. He is expected to refrain from such practices because of the importance of his duty that is the circumcision of boys.

The association of riding a baboon with witchcraft in the above lines clearly indicates how the practice of witchcraft is implied by using the baboon as symbol. The condition that the baboon rider would be forced to speak the truth indicates how he would be interrogated, should he be caught practising witchcraft. It further indicates the unacceptability of this practice.

Even breeding a baboon brings some suspicion of witchcraft among amaXhosa. That is the reason why the following is said about the people of Nkobonkobo:

Kuba bafuya kakubi xa bafuy' iimfene.

(For they breed badly when they breed baboons.)

(Burns-Ncamashe, 1961:110)

This statement stresses the idea that among amaXhosa the baboon is not regarded as being a good choice for breeding. Anyone who breeds it is normally accused of witchcraft, as it symbolises the practice. The use of the baboon as a familiar is clearly depicted by Sinxo $(1980: 36,40)$ in the instance where Velesazi sends Tsibamangcwaba (the baboon) to bewitch Nomsa, who rejects his constant pleas for a love relationship.

The use of the baboon as a symbol of witchcraft reveals BurnsNcamashe's familiarity with the cultural practices and beliefs of his people. Although no one may have actually been seen riding a baboon, since this practice would be a visible phenomenon, its use as a symbol enables the reader to form a mental picture of the action. The reader's being able to form a mental picture underlines the fact that the employment of the symbol can be regarded as successful. 


\section{Good motherhood}

Good motherhood is a phenomenon that is appreciated by society. To be called a good mother is a positive attribute one may be described with. The symbol of good motherhood used by BurnsNcamashe is the hen. The hen is known for her special care of her chickens. A hen will attack anything that interferes with her chickens; she is protective of her chickens. Her protectiveness becomes even more evident when she senses the presence of a hawk around. In such a situation the hen hides the chickens under her wings so that the hawk will not be able to catch them. Even during the night the chickens sleep covered under the hen's wings. The poet uses the hen as a symbol with regard to Queen Nobantu Sandile, as he views her as isikhukukazi sohlanga (the hen of the nation) (cf. BurnsNcamashe, 1961:12). This description suggests that Nobantu was not only a queen mother to amaRharhabe, but was regarded as a caring and protective person as well. These elements might have manifested themselves more clearly during the period when Nobantu was the queen regent and her son; Velile, was still too young to take up the reigns of supreme chieftainship.

Burns-Ncamashe's use of the hen to portray Nobantu as a good mother makes the reader, who knows how protective a hen is of her chickens, associate Nobantu with this bird. This association enables the reader to understand what the poet actually says about Nobantu. As the hen's protection of her chickens is a visible practice, its use as a symbol in this regard affords the reader an opportunity to form a mental picture of the bird protecting the young. The reader's ability to form a mental picture of the hen and the reader's understanding of what the poet actually says about Nobantu, reflect BurnsNcamashe's success in the use of the hen as a symbol of good motherhood.

\section{Strength}

There are animals that are specifically known for their strength especially in fighting. The animals that are used as symbols of strength by Burns-Ncamashe are the buffalo, the kudu and the bull.

The buffalo is a strong wild animal, fighting mainly with its horns. The use of this animal to symbolise strength is evident in the poem "Umthomb' onzulu wamanz' olwazi" in which the poet views Cecil John Rhodes as: 
Inyath' engenampondo edle ngamandla.

Ngubani n' ongaziyo, ingubani n' ongevanga,

Ukub' inyath' emandl' amnyam' isebenzile?

(The unhorned buffalo which boasts about strength.

Who does not know, and who has not heard,

That the black powered buffalo has worked?)

(Burns-Ncamashe, 1979:8, 11)

The poem from which these lines are taken points to Rhodes University, which is named after Cecil John Rhodes. The poet associates the university with Cecil John Rhodes, who is regarded to be its founder. By using the symbol of the buffalo to refer to Cecil John Rhodes, the poet expresses the strength he regards the latter to have had as he planned Rhodes University to be established. Another aspect associated with strength and mentioned in the poem is Rhodes's initiative in mining gold. The depiction of Rhodes as "the unhorned buffalo" may suggest that strong as he was, he was also harmless, as horns are normally used to harm or endanger an opponent. Rhodes then is viewed as strong, but harmless.

By associating the buffalo with Rhodes, the reader is able to understand what the poet actually says about Rhodes. The reader's ability to understand what the poet intends to say, points to the success with which this animal is used as a symbol of strength.

The use of the kudu as a symbol of strength is apparent in the poem "Aa! Heshangophondo" in which criticism is directed at Mavuso's method of ruling his subjects:

Nguhesha ngesheyi kubantu bakhe

Kub' uhesha ngophondo Iweqhude emadodeni,

Kant' uhesha ngondyilo kwababhinq' izikhaka.

(He rules with deception to his subjects

For he rules with a kudu horn to men,

While he rules with undyilo to those who wear skirts.)

(Burns-Ncamashe, 1961:109)

The kudu is a strong animal and fights by using its horns. The symbol of a "kudu horn" in the excerpt illustrates how strong (and strict) Mavuso might have been as a ruler to men. The contrast of a 
kudu horn with undyilo in the above lines should also be noted. Undyilo is the decorated part of isidla, which was used among amaXhosa to cover a male's penis before trousers were used (Mtuze \& Tena, 1995:193, 197). The use of undyilo as a symbol then indicates how promiscuous Mavuso the subject may have been. Instead of being strong to women, as he was to men, he probably seduced the former to have an intimate relationship with him.

Another symbol which is used to represent strength is inkunzi (the bull) (cf. Burns-Ncamashe, 1979:24, 28; 1961:109).

Apart from the aforementioned symbols there are also others, which are included in the poetry under study. These symbols include umthi (the tree) as a symbol of height in "Aa! Dalubuhle!" (unpublished), and imana (manna) as symbol of a free gift in "Intetho yohlanga Iwethu" ( $\mathrm{T}(\mathrm{XH} / 96) 5)$. The tree is a symbol from the plant world, while manna is a Biblical reference.

Of the symbols already discussed, there are those which are universal and those that apply to especially the amaXhosa. For instance, the symbols used for authority, grief and strength may be applied universally. On the other hand, there are those symbols that necessitate some background of amaXhosa culture and beliefs in order to be appreciated. This is especially true of the symbols used to depict witchcraft, as the baboon may not be regarded as a symbol of witchcraft in other communities.

\section{Conclusion}

This article has examined the way in which Burns-Ncamashe uses symbolism in his poetry and how he applies symbols originating from different "worlds": animals, plants humans, and references to the world of the Bible.

Burns-Ncamashe's artistic use of symbols adds to the high quality of his poetry. It also enhances the reader's understanding of the symbols employed in the poetry and therefore equips him/her with a better understanding of the meaning and message the poet wants to communicate. Apart from decorating his poetry, the symbols used in the poetry of Burns-Ncamashe also serve as instruments by which the reader's intellectual abilities are challenged, as the use of symbols urges the reader to engage his mental capacity to understand the message conveyed in a poem. The use of symbols also clarifies the meaning of the poem when the reader has 
discovered what the symbols refer to. Burns-Ncamashe's poetry is considered to be good poetry, as the symbols he applies contribute to the quality of his poetry.

Burns-Ncamashe's ability to use various types of applicable symbols, drawn from the different domains of life, illustrates his experience with these worlds. The poet's applying symbols from different domains of life and the functions fulfilled by these symbols contributes towards the success and lasting influende of his poetry.

\section{List of references}

ABRAMS, M.H. 1993. A glossary of literary terms. 6th edition. San Diago: Harcourt Brace Jevanovich College.

BALDICK, C. 1990. Oxford concise dictionary of literary terms. Oxford: Oxford University Press.

BURNS-NCAMASHE, S.M. "Aa! Dalubuhle". (Unpublished.)

BURNS-NCAMASHE, S.M. 1961. Masibaliselane. Cape Town: Oxford University Press.

BURNS-NCAMASHE, S.M. 1967. "Umnyaka omtsha" in $T(X H / 93) 28$. Port Elizabeth: SABC.

BURNS-NCAMASHE, S.M. 1976. "Aa! Velile!" in $T(X H / 90) 317$. Port Elizabeth: SABC.

BURNS-NCAMASHE, S.M. 1977. "UBazindlovu" in $T(X H / 90) 322$. Port Elizabeth: SABC.

BURNS-NCAMASHE, S.M. 1979. Izibongo zakwaSesile. Grahamstown: Iser.

BURNS-NCAMASHE, S.M. 1995. "Intetho yohlanga Iwethu" in $T(X H / 96) 5$. Port Elizabeth: SABC.

DABA, R. 1988. Izithethe zethu. Pretoria: Aktuapers.

GRAMBS, D. 1984. Literary companion dictionary. London: Routledge \& Kegan Paul.

LONGMANS DICTIONARY OF CONTEMPORARY ENGLISH. 1995. London: Longman.

MTUMANE, Z. 1992. Some aspects of Xhosa traditional thought as articulated in M.A.P. Ngani's play: Umkhonto ka Tshiwo. Alice: University of Fort Hare. (B.A. Honours assignment.)

MTUMANE, Z. 2000. The poetry of S.M. Burns-Ncamashe. Pretoria: University of South Africa. (Ph.D. thesis.)

MTUMANE, Z. 2001. Elements of satire in selected works of S.M. BurnsNcamashe. South African Journal of African Languages, 21(3):233-243.

MTUZE, P.T. \& TENA, W.M. 1995. Umhlobo wabafundi besiXhosa. Alice: Lovedale.

PEARSALL, J. 2001. Concise Oxford dictionary. Oxford: Oxford University Press.

SHAW, H. 1972. Dictionary of literary terms. New York: McGraw-Hill.

SHIPLEY, J.T. 1970. Dictionary of world literary terms. London: Allen \& Unwin.

SINXO, G.B. 1980. UNomsa. Alice: Lovedale.

TONJENI, E.V. M. 1959. Sihambele ubulawu Umtata: Bona Press. 


\section{Key concepts:}

Burns-Ncamashe

domains of reality

semiotics

symbolism in Burns-Ncamashe's poetry

\section{Kernbegrippe:}

Burns-Ncamashe

domeine van die werklikheid

semiotiek

simboliek in Burns-Ncamashe se poësie 